\title{
Can Asset Quality Promote the Sustainable Development of Enterprises?
}

\author{
Wei Yang, Shengdao Gan \\ Business School, Sichuan University \\ Chengdu, Sichuan, 610064
}

\begin{abstract}
Assets are the material basis of enterprise's profit. Therefore, asset quality is an important factor for enterprises to achieve sustainable development. This paper analyses the internal relationship between asset quality and the sustainable development of enterprises. Through empirical analysis, we find that asset quality is positively related to the sustainable development of enterprises, indicating that asset quality can indeed promote the sustainable development of enterprises. This study not only provides a new research perspective for the sustainable development of enterprises, but also meets the realistic requirements of high-quality economic development and enterprises' sustainable growth.
\end{abstract}

Keywords —asset quality; sustainable development; enterprises

\section{INTRODUCTION}

The global economy is facing downward pressure, and the economy has shifted from high-growth demand to high-quality development. As an important part of macro-economy, the quality of micro-economic entities will inevitably affect the overall quality of macro-economic development. Therefore, the quality of enterprise operation can not be ignored. In prior studies, the earnings quality of enterprises has been the focus of research [1-4], while little attention has been paid to the asset quality. Assets are the source of value for enterprises. The asset structure, liquidity, profitability and the proportion of non-performing assets will have an great impact on the operating results of enterprises. However, through literature review, it is found that most of the studies just focus on the quality of credit (banks, insurance companies) assets, and there are still few studies on the quality of enterprise assets, which cause a unified system has not yet been formed. Hence, we believe that it is necessary to pay more attention to the quality of assets when investigating the sustainable development ability of enterprises, and the asset quality is closely related to the operation ability and development potential of enterprises.

On the basis of theoretical analysis, this paper takes the financial data of listed manufacturing enterprises in China from 2010 to 2017 as the research sample. Firstly, it constructs the evaluation system of enterprise asset quality and makes a comprehensive score of enterprise asset quality by factor analysis, and finds the overall situation of asset quality of manufacturing enterprises in China is not good. Then, it examines that the asset quality indeed has a positive influence on the sustainable development of enterprises.

The innovations and possible contributions of this paper lie in the following aspects: Firstly, it enriches the content of asset quality evaluation system, constructs indicators from six aspects according to the characteristics and functions of assets. The content is relatively complete, the method is scientific and appropriate, which provides certain evaluation criteria for improving the quality of enterprise development. Secondly, we focus on the research of sustainable development ability of enterprises, the existing literatures mostly study the current performance or value of enterprises, neglecting the long-term development ability of enterprises. This paper can supplement this shortage.

\section{THEORY AND HYPOTHESES}

Because the sustainable growth rate of enterprises reflected by financial data can measure the long-term profitability and sustainable competitive advantage of enterprises [5], this paper focuses on the sustainable growth rate of enterprises to measure the sustainable development ability of enterprises.

Assets are the source of economic benefits for enterprises. Reasonable asset integration structure, asset liquidity and asset profitability and so on can affect the sustainable development ability of enterprises from different aspects. Firstly, good asset quality helps to reduce operating costs and agency costs. Bernstein (1996) studied the relationship between bank asset quality and economies of scale, and found that the worse the quality of bank assets, the higher the operating costs of banks [6]. Sibilkov (2009) studied the correlation between corporate asset liquidity and agency costs of managers, and concluded that the level of corporate asset liquidity is comparatively high and limited asset being saled can effectively reduce the agency cost of managers [7]. Secondly, the asset quality is directly related to the profitability and operating performance of enterprises. Beck and Levine (2004) measured the quality of assets by studying the impact of total credit and total investment on total assets, and concluded that the quality of assets will have a positive impact on profitability [8]. Bace (2016) verified that different aspects of asset quality will have an impact on profitability [9]. Song Xianzong and Gao Zhiwen (2001) believes that the low quality of assets will affect the profitability of the enterprise in the current year and the persistence of future profits [10]. Furthermore, Zhang Zhihong and Sun Qing (2015) empirically tested that strengthening the governance of asset quality of listed companies contributes to the formation of high-quality earnings, and has a conductive role in improving corporate value [11]. In addition, according to the signal theory, the high-quality assets disclosed by accounting information can release positive signals for enterprises, enhance the confidence 
of investors in enterprises, ease the financing constraints of enterprises, and also contribute to the sustainable development of enterprises. It can be seen that the improvement of asset quality not only brings the book profit of enterprises, but also fundamentally improves the profit structure, development mode and market value in the long run, thus forming a virtuous circle, realizing the sustainability of profits and enhancing the sustainable growth ability of enterprises. Thus, the main research hypothesis is put forward:

Hypothesis: Asset quality is positively correlated with the level of sustainable development of enterprises.

\section{METHODS AND VARIABLES}

\section{A. Sample and Data}

This research selects China's A-share listed manufacturing companies from 2010 to 2017 as the original sample to eliminate the impact of financial crisis on sustainable development of enterprises, and to ensure the similarity and comparability of enterprises' asset quality in the same industry. We screened the samples as follows: (1) excluding the firms with special treatment or particular transfer (ST or PT firms); (2) excluding those with missing values for variables (3) to avoid the influence of extreme values, we also winsorized all main financial variables at the top and bottom $1 \%$, and finally obtained 9,661 sample observations. The main data of the variables used in this paper were obtained from the China Stock Market and Accounting Research Database (CSMAR).

\section{B. Measurement of Variables}

Dependent variables: Robert C. Higgins [12] and James C. Van Horn [13] are the most representative scholars to study the sustainable growth of enterprises. They both use
Sustainable Growth Rate (SGR) to judge whether enterprises have achieved sustainable growth, and build corresponding sustainable growth models. Higgins (1977) establishes a static model of sustainable growth, which considers that sustainable growth rate refers to the maximum ratio of sales growth without exhausting financial resources. The advantage of this model is that it is easy to understand and operate. Van Horne's sustainable growth model studies enterprise growth from a dynamic perspective, emphasizing that sustainable growth rate is the maximum annual growth rate of company sales determined by the target value of operating ratio, debt ratio and dividend payment ratio, and it is a target value rather than a real growth rate [14]. In order to ensure the reliability of this study, we use the sustainable growth rate calculated in two ways as dependent variables to make regression analysis of the models.

Independent variables: Scholars use different ways to measure asset quality in their research. Earlier asset quality was expressed as a single $\mathrm{K}$-value ratio ( $\mathrm{K}=\mid$ adjusted net assets per share-net assets per share |/net assets per share), [10] [15], but this method is not appropriate. Primarily, in 2007, the SFC cancelled the requirement of disclosure of "adjusted net assets per share". Then, the allocation of enterprise assets is very complex, and only measuring the ratio of effective assets to total assets can not reflect other important characteristics of assets. As a result, the main way to measure asset quality in China is to start with the characteristics of asset quality and select representative indicators to build a comprehensive evaluation system. Based on previous studies [11] [16-18], we construct an evaluation system by selecting 16 characteristic indicators from six aspects: the authenticity, turnover, profitability, development, structure and safety of assets, as the following table I.

TABLE I ASSET QUALITY EVALUATION INDICATORS

\begin{tabular}{|c|c|c|}
\hline Characteristics & Indicator & Computational formulas \\
\hline Authenticity & Ratio of Real Assets & $\begin{array}{l}\text { 1- non-performing assets ratio }=1 \text { - ( Long-term unamortized expenses }+ \\
\text { more-than-hree-years accounts receivable }+ \text { deferred income tax assets }) / \\
\text { total assets }\end{array}$ \\
\hline \multirow[t]{5}{*}{ Liquidity } & Inventory turnover & Operating cost/Average inventory \\
\hline & Receivable turnover & Operating revenue/ Average receivable \\
\hline & Current assets turnover & Operating revenue/ Average current assets \\
\hline & Fixed assets turnover & Operating revenue/ Average fixed assets \\
\hline & Total asset turnover & Operating revenue/ Average total assets \\
\hline \multirow[t]{2}{*}{ Profitability } & Return on assets & EBIT/Average total assets \\
\hline & Cash recovery of assets & Net operating cash flow / Average total assets \\
\hline \multirow[t]{2}{*}{ Development } & Growth rate of fixed assets & $\begin{array}{l}\text { ( Fixed assets in the end of this year - Fixed assets in the end of last year)/ } \\
\text { Fixed assets in the end of last year }\end{array}$ \\
\hline & Growth rate of total assets & $\begin{array}{l}\text { ( Total assets in the end of this year - Total assets in the end of last year)/ } \\
\text { Total assets in the end of last year }\end{array}$ \\
\hline \multirow[t]{4}{*}{ Structure } & Proportion of current assets & Current assets /Total assets \\
\hline & Proportion of fixed assets & Fixed assets /Total assets \\
\hline & Proportion of intangible assets & Intangible assets /Total assets \\
\hline & Proportion of tangible assets & (Total assets - Intangible assets - goodwill) /Total assets \\
\hline \multirow[t]{2}{*}{ Safety } & Liquidity ratio & Average current assets / Average current debt \\
\hline & Total asset ratio & Average total assets / Average total debt \\
\hline
\end{tabular}


We can not only overcome the multi-collinearity between the indicators, but also explain the influencing factors of asset quality with fewer common factors without missing the main information by using factor analysis to calculate the score of asset quality. Firstly, Bartlett- spherical test was carried out for each index, and the $\mathrm{P}$ value was significantly less than $1 \%$. The original hypothesis that there was no multiple collinearity among the indexes was rejected, which indicated that the index we selected was more suitable for factor analysis. Then, seven principal components (f1-f7) were extracted according to the criterion of an eigenvalue greater than 1. Taking the variance contribution rate of each factor as the factor weight, the comprehensive score of the overall asset quality is calculated as the following formula. The higher the AQ score, the higher the asset quality of the enterprise in that period.

\section{$\mathrm{AQ}=0.1841 * \mathrm{f} 1+0.1830 * \mathrm{f} 2+0.1826 * \mathrm{f} 3+0.1542 * \mathrm{f} 4$ $+0.1036 * \mathrm{f} 5+0.1002 * \mathrm{f} 6+0.0924 * \mathrm{f} 7$}

Contro variables: Referring to the previous literature[5,11,19-22], we also consider other factors affecting the sustainable growth of enterprises, and add the following control variables: the size of the company. Enterprise risk. Internal control. Corporate governance, including the size of the board of directors,the proportion of the first largest shareholder and the combination of two positions. The nature of property rights. In addition, audit quality can reflect the quality of financial information disclosure, affect the reliability of asset quality and the evaluation of enterprise growth ability. Finally, considering the location of the company. Specific definitions of these variables are provided in Table II.

\begin{tabular}{|c|c|c|}
\hline Variables & Symbol & Definitions \\
\hline $\begin{array}{l}\text { Sustainable growth rate } \\
\text { (Higgins) }\end{array}$ & $S G R \_H$ & $\begin{array}{l}\text { SGR_H }=\mathrm{P} \times \mathrm{Q} \times \mathrm{L}_{0} \times \mathrm{R} \text {, where } \mathrm{P} \text { represents the profit margin (net } \\
\text { profit/total sales), Q represents the asset turnover rate (total sale/total asset), } \\
\mathrm{L}_{0} \text { represents the leverage factor (total asset/beginning-of-period equity), and } \mathrm{R} \\
\text { represents the percentage of earnings retained. }\end{array}$ \\
\hline $\begin{array}{l}\text { Sustainable growth rate } \\
\text { (Van Horn) }\end{array}$ & $S G R \_V$ & $\begin{array}{l}\text { SGR_V }=\mathrm{P} \times \mathrm{Q} \times \mathrm{L} \times \mathrm{R} /(1-\mathrm{P} \times \mathrm{Q} \times \mathrm{L} \times \mathrm{R}) \text {, where } \mathrm{P} \text { represents the } \\
\text { profit margin(net profit/total sales), } \mathrm{Q} \text { represents the asset turnover rate (total } \\
\text { sale/total asset), } \mathrm{L} \text { represents the leverage factor (total asset/end-of-period equity), } \\
\text { and } \mathrm{R} \text { represents the percentage of earnings retained. }\end{array}$ \\
\hline Asset quality & $A Q$ & $\begin{array}{l}\text { Comprehensive score obtained by factor analysis based on asset quality } \\
\text { evaluation index. }\end{array}$ \\
\hline Enterprise size & SIZE & $\operatorname{Ln}($ the end-of-period total assets) \\
\hline Enterprise risk & $R I S K$ & $\begin{array}{l}\text { (Depreciation of depreciation, oil and gas assets }+ \text { depreciation of productive } \\
\text { biological assets }+ \text { amortization of intangible assets }+ \text { amortization of long-term } \\
\text { pending expenses) /(net profit }+ \text { income tax expenses) }\end{array}$ \\
\hline Internal control & $I C$ & Ln(Dibo internal control index) \\
\hline Board size & DSIZE & $\mathrm{Ln}$ (the number of board members) \\
\hline $\begin{array}{l}\text { The largest sharehold } \\
\text { holdings }\end{array}$ & FSH & Number of shares held by the largest shareholder / total shares of the company \\
\hline Integration of two positions & $D U A L$ & $\begin{array}{l}\text { When the chairman and general manager are appointed by the same person, it } \\
\text { takes } 1 \text {; otherwise, it takes } 0 \text {. }\end{array}$ \\
\hline Property right & $S O E$ & $\begin{array}{l}\text { When the final control of a listed company is artificially state-owned, it takes } 1 \text {; } \\
\text { otherwise, it takes } 0 \text {. }\end{array}$ \\
\hline Audit quality & AUDIT & $\begin{array}{l}\text { When the annual audit report is issued by four major international or ten major } \\
\text { domestic accounting firms and the audit opinions are the standard opinions, it } \\
\text { takes } 1 \text {; otherwise, it takes } 0 \text {. }\end{array}$ \\
\hline Location & LOCATION & $\begin{array}{l}\text { Referring to Wang Xiaolu and Fangang's method of dividing China's eastern, } \\
\text { central and Western regions, and Controlling the influence of macroeconomic } \\
\text { factors in different years }\end{array}$ \\
\hline Year & YEAR & Controlling the influence of time factors in different years \\
\hline
\end{tabular}

\section{Model Design}

In order to test the relationship between asset quality and sustainable development of enterprises, we build the following model:

$$
\begin{gathered}
S G R_{t}=\beta_{0}+\beta_{1} A Q_{t}+\sum \beta_{n} \text { Control }_{S}+\varepsilon \\
\alpha+\beta=\chi .
\end{gathered}
$$




\section{RESULTS}

\section{A. Descriptive Statistics}

Table III is the descriptive statistical results of the main variables in this model. Higgins' sustainable growth rate (SGR_H) average is 0.0695 , which shows that, on the whole, the sustainable growth ability of enterprises is $6.95 \%$ per year, $50 \%$ of enterprises' sustainable growth rate is less than $5.43 \%$, and $75 \%$ of enterprises' sustainable growth rate is less than $9.65 \%$. This shows that only a few enterprises have high-speed sustainable growth ability. Van Horn's sustainable growth rate (SGR_V) is slightly lower than Higgins's overall sustainable growth rate, but the distribution is similar, with an average sustainable growth rate of $6.30 \%$.

Regarding other control variables, the mean value of SIZE is 21.92, RISK is 3.015 and $50 \%$ is 1.559 , which indicates the risk distribution is not uniform in the industry. The average internal control index is 6.504 after logarithm, which is relatively concentrated with little difference. The average size of the board is 2.136. The average shareholding ratio of the largest shareholder is $34.5 \%$. In addition, $28.4 \%$ of enterprises have the same chairman and general manager. $31.9 \%$ of the samples are state-owned holding enterprises. $66.7 \%$ of the sample enterprises have good audit quality.

TABLE III DESCRIPTIVE STATISTICS OF MAJOR VARIABLES

\begin{tabular}{|c|c|c|c|c|c|c|}
\hline Variable & $\mathrm{N}$ & mean & $\mathrm{sd}$ & $\mathrm{p} 25$ & $\mathrm{p} 50$ & $\mathrm{p} 75$ \\
\hline SGR_H & 9661 & 0.0695 & 0.0631 & 0.0247 & 0.0543 & 0.0965 \\
\hline$S G R \_V$ & 9661 & 0.0630 & 0.0561 & 0.0225 & 0.0500 & 0.0868 \\
\hline$A Q$ & 9661 & 0.00484 & 0.203 & -0.136 & -0.00448 & 0.133 \\
\hline SIZE & 9661 & 21.92 & 1.143 & 21.11 & 21.77 & 22.54 \\
\hline RISK & 9661 & 3.015 & 7.812 & 1.236 & 1.559 & 2.428 \\
\hline$I C$ & 9661 & 6.504 & 0.120 & 6.460 & 6.520 & 6.563 \\
\hline DSIZE & 9661 & 2.136 & 0.188 & 1.946 & 2.197 & 2.197 \\
\hline$F S H$ & 9661 & 0.345 & 0.143 & 0.235 & 0.330 & 0.436 \\
\hline$D U A L$ & 9661 & 0.284 & 0.451 & 0 & 0 & 1 \\
\hline$S O E$ & 9661 & 0.319 & 0.466 & 0 & 0 & 1 \\
\hline LOCATION & 9661 & 2.549 & 0.721 & 2 & 3 & 3 \\
\hline
\end{tabular}

\section{B. Regression Results}

In order to test the relationship between asset quality and sustainable development of enterprises, we use Higgins' sustainable growth rate and Van Horn's sustainable growth rate as dependent variables to regression model (1). The results are as Table IV. Column (1) (3) is the regression result without controlling variables. The $A Q$ coefficients are 0.023 and 0.032 , respectively, and are significant at the level of $1 \%$. This shows that asset quality has a positive effect on the sustainable growth rate of enterprises without considering other factors. Column (2) (4) is the regression result after adding other control variables. The $A Q$ coefficients are 0.017 and 0.026 respectively, and are still significantly positive at $1 \%$ level. This shows that the sustainable growth rate of enterprises calculated by Higgins and Van Horn models will increase by $1.7 \%$ and $2.6 \%$ for each unit of asset quality improvement, which proves once again that the asset quality of enterprises contributes to the sustainable growth capacity of enterprises. Assuming Hypothesis 1 is supported. Furthermore it can be found that enterprise scale, enterprise risk, internal control and property right nature will also have a significant impact on the sustainable growth rate of enterprises. Specifically, the larger the enterprise scale and the better the internal control, the higher the sustainable growth rate of enterprises; the higher the risks faced by enterprises, the lower the sustainable growth rate; the sustainable growth rate of enterprises with state-owned property right nature may be lower than that of non-state-owned property.

TABLE IV REGRESSION OF ASSET QUALITY AND SUSTAINABLE DEVELOPMENT OF ENTERPRISES

\begin{tabular}{|c|c|c|c|c|}
\hline VARIABLES & (1) & (2) & (3) & (4) \\
\hline & $S G R \_H$ & SGR_H & $S G R \_V$ & $S G R \_V$ \\
\hline$A Q$ & $\begin{array}{c}0.023 * * * \\
(4.68)\end{array}$ & $\begin{array}{c}0.017 * * * \\
(3.75)\end{array}$ & $\begin{array}{c}0.032 * * * \\
(6.88)\end{array}$ & $\begin{array}{c}0.026 * * * \\
(6.02)\end{array}$ \\
\hline SIZE & & $\begin{array}{c}0.010^{* * * *} \\
(8.77)\end{array}$ & & $\begin{array}{c}0.007 * * * \\
(7.05)\end{array}$ \\
\hline$R I S K$ & & $\begin{array}{c}-0.002 * * * \\
(-4.12)\end{array}$ & & $\begin{array}{c}-0.001 * * * \\
(-4.06)\end{array}$ \\
\hline$I C$ & & $\begin{array}{c}0.105^{* * *} * \\
(9.49)\end{array}$ & & $\begin{array}{c}0.093 * * * \\
(9.36)\end{array}$ \\
\hline DSIZE & & -0.007 & & -0.004 \\
\hline
\end{tabular}




\begin{tabular}{|c|c|c|c|c|}
\hline \multicolumn{5}{|c|}{ Table IV, cont } \\
\hline & & $(-1.39)$ & & $(-0.84)$ \\
\hline \multirow[t]{2}{*}{$F S H$} & & -0.005 & & 0.003 \\
\hline & & $(-0.70)$ & & $(0.52)$ \\
\hline \multirow[t]{2}{*}{$D U A L$} & & 0.001 & & 0.001 \\
\hline & & $(0.61)$ & & $(0.49)$ \\
\hline \multirow[t]{2}{*}{$S O E$} & & $-0.005^{* *}$ & & -0.003 \\
\hline & & $(-2.05)$ & & $(-1.18)$ \\
\hline \multirow[t]{2}{*}{$A U D I T$} & & 0.003 & & 0.003 \\
\hline & & $(1.43)$ & & $(1.58)$ \\
\hline LOCATION & control & control & control & control \\
\hline$Y E A R$ & control & control & control & control \\
\hline \multirow[t]{2}{*}{ Constant } & $0.092 * * *$ & $-0.782 * * *$ & $0.081 * * *$ & $-0.671 * * *$ \\
\hline & $(23.70)$ & $(-10.54)$ & $(23.15)$ & $(-9.94)$ \\
\hline Observations & 9,661 & 9,661 & 9,661 & 9,661 \\
\hline$A d j \_R^{2}$ & 0.0256 & 0.139 & 0.0343 & 0.141 \\
\hline
\end{tabular}

\section{CONCLUSION}

With the increasing downward pressure in economics, it is very important for enterprises to achieve high-quality sustainable development through their own efforts, such as improving the asset quality which is the most fundamental way. This paper takes the listed manufacturing enterprises in China from 2010 to 2017 as the research object, and empirically analyses the mechanism of the material basis of enterprises - asset quality on the sustainable development ability of enterprises. The results show that the overall situation of asset quality of listed manufacturing enterprises in China evaluated by factor analysis method is not ideal. Most of the enterprises' asset quality is below the average level, and there is still much room for improvement. At the same time, asset quality indeed promotes sustainable growth of enterprises. The research is based on the subjective important factor in the process of enterprise operation, and the conclusion has great practical enlightenment.

The above conclusions help us realize that the important thing of improving the sustainable development ability of enterprises is to improve the quality of assets. However, there are still some limitations in this study. For example, is there any other variable that regulates the relationship between asset quality and sustainable development? What are the specific factors made by asset quality that to drive the sustainable development of enterprises? Due to the limitation of space, we do not carry out an extended study. Absolutely, the above shortcomings need to be explored in other articles.

\section{ACKNOWLEDGMENT}

Wei Yang (1989-), female, born in Guizhou province, a doctoral student from the Business School of Sichuan University; her research direction is financial management as well as the sustainable development of enterprises.

Shengdao Gan (1967-), male, born in Anhui province, a professor and doctoral supervisor from the Business School of Sichuan University; his research direction is accounting and financial management

The authors declare no conflicts of interest.

\section{REFERENCES}

[1] Easton, P. D . Studies on Accounting Earnings and Security Valuation: Empirical Evidence of the Fundamental Links. Journal of Accounting Research, 1985, 23, 54-77.

[2] Lev, B.; Thiagarajan, S. R. Fundamental Information Analysis. Journal of Accounting Research, 1993, 31,190-215.

[3] Velury, U.; Jenkins, D. S. Institutional ownership and the quality of earnings. Journal of Business Research, 2006, 59, 1043-1051.

[4] Francis, J.; Huang, A. H.; Rajgopal, S.; et al. CEO Reputation and Earnings Quality. Contemporary Accounting Research, 2008, 25, 109 147.

[5] Wang, H.; Han, B. Social Responsibility, Internal Control and Sustainable Development of Enterprises: An Empirical Analysis of Listed Companies Based on A-share Main Board. Journal of Beijing Business University (Social Science Edition), 2016, 31, 75-84.

[6] Bernstein, D . Asset quality and scale economies in banking. Journal of Economics and Business, 1996, 48, 157-166.

[7] Sibilkov; Valeriy. Asset Liquidity and Capital Structure. Journal of Financial and Quantitative Analysis, 2009, 44, 1173-1196.

[8] Beck, T.; Levine, R. Loayza N . Finance and the Sources of Growth. Journal of Financial Economics, 2004, 58, 261-300.

[9] Bace, E. Bank profitability: Liquidity, capital and asset quality. Journal of Risk Management in Financial Institutions, 2016, 9, 327-331.

[10] Song, X.; Gao, Z. An Empirical Analysis of Asset Quality Reflecting Profitability. China's Industrial Economy, 2001, 4, 78-80.

[11] Zhang; Z.; Sun, Q. Asset Quality, Earnings Quality and Corporate Value. Financial Economics Research, 2016, 3, 85-97.

[12] Higgins, R. C. How Much Growth Can a Firm Afford?. Financial Management, 1977, 6, 7-16.

[13] Horne, J. V.; Wachowicz, J. Fundamentals of Financial Management. Prentice Hall: Upper Saddle River, N J, USA

[14] Tang, G.; You, Y. Comparative Analysis and Case Validation of Sustainable Growth Model. Accounting Research, 2005, 8, 50-55.

[15] Fei, M.; Gan, S. Asset Quality Analysis - Based on the Data of Listed Companies in China. Financial Communication, 2004, 10, 10-12.

[16] Zhang, X.; Wang, X. Quality Characteristics of Enterprise Financial Situation. Accounting Research, 2003, 9, 35-38.

[17] Zhang, C.; Xu, W. Empirical Analysis of Asset Quality Assessment of Listed Companies in China. Monthly Journal of Finance and Accounting, 2006, 2, 19-21

[18] Qian, A.; Zhou, Z. Construction and test of evaluation index system of operational assets quality: empirical evidence from A-share listed companies in China's chemical industry. Management Review, 2009, 10, 109-115.

[19] Li, H.; Qianwei, Y.; Shanye, Y.; Hazrat, H . Trade Credit Financing 
and Sustainable Growth of Firms: Empirical Evidence from China. Sustainability, 2019,11,1-20

[20] Yang, X.; Peng, C.; Yao, A. Management Capability, Internal Control and Corporate Sustainability. Audit Research, 2018, 3, 121-128.

[21] Luís, C. Sunk Costs, Firm Size and Firm Growth. Journal of Industrial Economics, 1995, 43, 161-172.

[22] Brown, P. R.; Beekes, W.; Verhoeven, P. Corporate Governance, Accounting and Finance: A Review. Social Science Electronic Publishing, 2014, 51, 96-172. 